\title{
Chapter 20 \\ Access to Social Protection by Immigrants, Emigrants and Resident Nationals in Switzerland
}

\author{
Bettina Kahil-Wolff Hummer
}

\subsection{Overview of the Welfare System and Main Migration Features in Switzerland}

The link between migration and welfare in Switzerland has great practical relevance given the number of persons migrating in and out of Switzerland. More than one third of the population has a migrant background and a bit less than one third of gainful activities in Switzerland are accomplished by foreigners. ${ }^{1}$ The persons concerned integrate both into the Swiss job market and social security, as tax and social contribution payers and, potentially, as beneficiary of social benefits. The Swiss social security system also covers individuals living or working outside Switzerland, more particularly, Swiss citizens and European Union (EU)/European Free Trade Association (EFTA) nationals. In many ways, the Swiss social security has therefore to respond to migration-related questions that are relevant to this research (Kahil-Wolff 2017).

\footnotetext{
${ }^{1}$ Federal statistical office 2017, Statistischer Bericht zur Integration der Bevölkerung mit Migrationshintergrund, Neuchâtel.

B. Kahil-Wolff Hummer $(\triangle)$

Faculty of Law, Criminal Science and Public Administration, University of Lausanne,

Lausanne, Switzerland

e-mail: Bettina.Hummer@unil.ch
} 


\subsubsection{Main Characteristics of the Swiss Social Security System}

In Switzerland, almost all social protection schemes are provided by the Federal social security system (Riemer-Kafka 2018). The Federal Constitution ${ }^{2}$ supplies the Federal State with the necessary legislative competences in the field of pensions (Article 111), illness and accident insurance (Article 117), maternity leave (Article 116), unemployment (Article 114) and all other social risks listed in the ILO Convention 102. Social assistance - although it is mentioned in article 12 of the Constitution - is not regulated at the federal level (except for Swiss nationals residing abroad), but by the legislation of the 26 autonomous Swiss cantons. International law plays a major role as most migrants move between Switzerland and EU/EFTA Member States, hence triggering the application of EU coordination rules (EU Regulations $n^{\circ} 883 / 2004$ and $n^{\circ}$ 987/2009) and the right to free movement of persons. ${ }^{3}$

The Federal social security system of Switzerland is based on 10 different branches which provide protection against social risks related to old-age, death, invalidity, illness, accidents, maternity, unemployment and family charges. Each branch has the shape of a compulsory public social insurance based on public law. The different insurance branches are financed mostly by contributions (paid by insured persons, workers, employers) and partly by taxes. General principles and procedures are regulated by the Federal Law on the General Part of Social Insurance (LPGA) ${ }^{4}$ The organization of all social security schemes is decentralized. It relays on independent public and private bodies monitored by federal authorities such as the Federal Office for Social Insurances (OFAS) and the Federal Office for Public Health (OFSP).

For each branch, the statutory law clearly defines the insured persons, the risks covered, and the benefits provided. Hence, insurance institutions cannot - with few exceptions - adopt autonomous provisions. Whereas some branches are covering the entire population (public pension system for old-age, survivors and invalidity/ illness insurance), others are mandatory for workers only (complementary pension scheme/public accident insurance/unemployment insurance). Self-employed persons may ensure themselves on a voluntary basis in the public accident insurance (LAA) and in the complementary pension scheme (LPP, 2nd pillar). In each social security scheme, including the sickness insurance, persons are insured individually but never as family members.

\footnotetext{
${ }^{2}$ Recueil systématique du droit fédéral, RS 101. Based on art. $14 \S 6$ of the Federal Act on the Compilations of Federal Legislation and the Federal Gazette (Publ A, RS 170.512), the Federal Chancellery may publish legal texts of particular importance or international interest in English; the present report refers to the English version whenever available.

${ }^{3}$ European Court of Justice, European Case Law Identifier, ECLI:EU:C:2011:839, § 43

${ }^{4}$ Loi fédérale sur la partie générale du droit des assurances sociales, LPGA, RS 830.1
} 
There is no National Health Service in Switzerland. Access to health care is provided through social insurances such as the ones for illness (LAMal), ${ }^{5}$ accidents (LAA), ${ }^{6}$ invalidity (LAI), ${ }^{7}$ or the military insurance (LAM) ${ }^{8}$ Whereas the illness insurance reimburses the expenses of insured persons, all other branches function by direct and full payment (the care providers are paid by the insurer). There is no mandatory sickness leave insurance. Workers and employers may conclude a public voluntary sickness insurance or a private one. Without such insurance, employers must pay the wages during a period of time that depends on the duration of employment (Geiser et al. 2019). Compulsory coverage of inability to work, however, is provided by other mandatory social insurance branches when related to maternity, accidents, work injuries, injuries in military activities or measures concerning the integration of disabled persons. Old-age, survivor and disability pensions are provided through a three-pillar system granted by the Federal Constitution. They rely on a public minimum scheme that is pay-as-you-go based and covers the whole population (LAVS, 1st pillar), ${ }^{9}$ a capitalized complementary pension scheme focused on workers earning more than CHF 21.330 per year (LPP, 2nd pillar) ${ }^{10}$ and on individual tax deductible savings (3rd pillar). Non-contributory old-age, survivor and disability benefits are paid to pension holders if the public pension does not cover the vital minimum (LPC). ${ }^{11}$

Swiss social security also includes family benefits (LAFam and LFA), ${ }^{12}$ maternity leave benefits (LAPG) $)^{13}$ and unemployment benefits (LACI). ${ }^{14}$ Some benefits (such as health care and pensions) overlap because they partly cover identical groups of persons and risks. LPGA and special provisions therefore ensure the coordination of those benefits to prevent unjustified multiple coverage or unintended lacks (Frésard-Fellay and Frésard 2018).

\footnotetext{
${ }^{5}$ Loi fédérale sur l'assurance-maladie, LAMal, RS 832.10

${ }^{6}$ Loi fédérale sur l'assurance-accidents, LAA, RS 832.20

${ }^{7}$ Loi fédérale sur l'assurance-invalidité, LAI, RS 831.20

${ }^{8}$ Loi fédérale sur l'assurance militaire, LAM, RS 833.1

${ }^{9}$ Loi fédérale sur l'assurance-vieillesse et survivants, LAVS, RS 831.10

${ }^{10}$ Loi fédérale sur la prévoyance professionnelle, LPP, RS 831.40

${ }^{11}$ Loi fédérale sur les prestations complémentaires, LPC, RS 831.30

${ }^{12}$ Loi fédérale sur les allocations familiales, LAFam, RS 836.2; Loi fédérale sur les allocations familiales dans l'agriculture, LFA, RS 836.1

${ }^{13}$ Loi fédérale sur les allocations pour perte de gain, LAPG, RS 834.1

${ }^{14}$ Loi fédérale sur l'assurance-chômage obligatoire et l'indemnité en cas d'insolvabilité, LACI, RS 837.0
} 


\subsubsection{Migration History and Key Policy Developments}

In Switzerland, like in most European countries, social protection regulation started in the late nineteenth century, under the influence of the growing industrialization and the risk of personal injuries caused to workmen. As one can see from the sickness and accident insurance created after 1911, the Swiss social protection system is partly inspired by the Bismarckian system, with a series of mandatory, strongly decentralized public insurance schemes. Currently, Swiss social security law also provides a certain number of protection schemes that apply to the whole population (especially in order to cover the risks of sickness, old age, disability and death).

Some important social security developments occurred in parallel with demographic changes. After the second World War when Switzerland started building the national pension system, economic growth triggered a need of foreign labor force that was mostly satisfied by Italian workers. In 1951, a few years after the creation of the Swiss public pension system, a first social security agreement was concluded between Italy and Switzerland to protect Italian migrant workers. Social security agreements with Germany (1964), Austria (1967) and France (1975) followed in the attempt to address economic relations and migration related issues with those countries. Other cornerstones in the field of social protection for migrants can be found in the law of the land. The Swiss public pension system, including the disability insurance created in 1959, first included a waiting period of 10 years before insured foreigners were entitled to an old-age, survivor or disability pension. At that time, the legislator intended to favor migrants from countries that would give equal treatment to Swiss citizens on their territory, via national law or bilateral agreements (Binswanger 1950). This discriminating rule was lowered to a 1 year waiting period in 1997. Since June 2001, the situation of most migrants living and/or working in Switzerland are subject to EU Regulations $n^{\circ} 883 / 2004$ and $n^{\circ} 987 / 2009$. At the same time, the federal legislator narrowed the access to the public pension system for Swiss citizens living abroad; today, Swiss citizens (as well as EU citizens) may adhere to the system only if living outside an EU or EFTA country and after a fiveyear prior insurance period (see Sect. 20.2.3 below).

Today, the largest group of foreigners living or working in Switzerland are EU and EFTA citizens. According to the Foreign Population and Asylum Statistics 2017, published by the Federal State Secretariat for Migration (SEM) in March 2018, around $70 \%$ of the permanent foreign resident population come from European countries, with Italy first (319.367 persons), Germany second (305.785 persons) and Portugal third (268.012 persons). The main reasons for migration towards Switzerland are the Swiss job market (47\% take up employment) and family reunification (31\% of migrants arrive to Switzerland for this reason). ${ }^{15} \mathrm{~A}$ decade ago, the SEM reported about the constant increase of migration in Switzerland, with

\footnotetext{
${ }^{15}$ Federal State Secretariat for Migration, Foreign Population and Asylum Statistics 2017. https:// www.sem.admin.ch/dam/data/sem/publiservice/statistik/bestellung/auslaender-asylstatistik2017-e.pdf
} 
two million persons immigrating to Switzerland since the end of World War II and 1.5 million foreign nationals in $2007 .{ }^{16}$ In 2019, Switzerland hosted around 2 million foreigners out of 8,4 million inhabitants (hence, $23,8 \%$ of the total population). The situation is different in the field of emigration. Only one-tenth of Swiss citizens live abroad. This percentage is mostly stagnant, with $10 \%$ in $2007^{17}$ and $11 \%$ in $2018 .{ }^{18}$ A majority of non-resident Swiss citizens live in Europe, especially in France, where they settle for retirement. ${ }^{19}$

\subsection{Migration and Social Protection in Switzerland}

With some exceptions, the Swiss social security law does not distinguish between nationals and foreigners. Most social security branches are based on the idea that individuals must be insured according to the rules of domicile and/or lex loci laboris. As long as a person fulfills the conditions required by the law, he/she is insured no matter his/her origin or nationality. The federal law concerning the General Part of Social Insurance (LPGA) does not contain any rules either that make a distinction between nationals and foreigners. However, there are special rules in areas such as the exportability of public pensions, access to the voluntary public pension scheme for individuals living abroad or access to invalidity benefits. As explained below, these rules require Swiss/EU/EFTA citizenship. About 20 bilateral social security agreements, the Free Movement of Persons Agreement (Switzerland-EU) and the ETFA Agreement (Switzerland, Liechtenstein, Norway, and Iceland) waive most of the discriminating national rules. Towards EU/EFTA Member States, Switzerland applies EU Regulations $n^{\circ} 883 / 2004$ and $n^{\circ}$ 987/2009. However, these Regulations do not cover social assistance so that, even when the Free Movement of Persons Agreement and the EFTA Agreement are applicable, Switzerland may still refuse social aid to inactive persons who are not workers or self-employed.

Foreigners' access to social benefits in Switzerland is also constrained by the migration rules in the federal law. As a result of a popular vote in 2014, a new provision stipulates that the administration will not issue a residence permit to foreigners who apply for non-contributory benefits paid to old-age, survivor or disability pension holders provided by the federal complementary scheme (LPC). The new rules also state that foreign job-seekers and their families do not qualify for social assistance (art. 29a Federal Act on Foreign Nationals, FNA, RS 142.20). Concerning persons who fall into the scope of the Free Movement of Persons Agreement, FNA specifically stipulates that it is not applicable to these persons unless the legal act

\footnotetext{
${ }^{16}$ Federal Office for Migration, Migration Report 2007, p. 7. https://www.sem.admin.ch/dam/data/ sem/publiservice/berichte/migration/migrationsbericht-2007-e.pdf

${ }^{17}$ Federal Office for Migration, Migration Report 2007, p. 7.

${ }^{18}$ Federal Statistical Office, Press release, Swiss abroad in 2018, https://www.bfs.admin.ch/bfs/en/ home. assetdetail.7826275.html

${ }^{19}$ Federal Statistical Office, Press release, Swiss abroad in 2018.
} 
contains rules that are more advantageous than the FMP Agreement. The revision of the Immigration Law did also lead to certain modifications of social security law. The new provisions restrict the access to non-contributory pensions (art. 5 LPC now stipulates that complementary benefits are provided only to foreigners who have a legal residence in Switzerland) and allow the data exchange between social security institutions and border protection authorities. Concerning the disability insurance, the federal law also allows to ask the assistance of immigration authorities when dealing with cases of insured persons (article 59 LAI). Furthermore, there is a new rule requiring a six-months waiting time for migrants to qualify for unemployment benefits (article 14 LACI). The new rules entered into force on July 1st 2018 and January 1 st 2019.

Most of the new regulations, however, are not applicable to those who fall into the scope of EU Regulations $n^{\circ} 883 / 2004$ and $n^{\circ} 987 / 2009$. Those migrants are protected by the European coordination rules (Kahil-Wolff 2015). These Regulations contain certain rules that derogate national law and apply to all branches of social security (for instance, a national rule requires residency in Switzerland as a condition to get family benefits, whereas Regulation $n^{\circ} 883 / 2004$ waives such condition by providing exportation of benefits).

\subsubsection{Unemployment}

The federal unemployment insurance covers all workers, regardless of their nationality. Nevertheless, the insured person has to fulfill certain requirements that could restrain foreigners' access to unemployment benefits. The law requires to be without a job, effectively reside in Switzerland (Rubin 2014), comply with a 12-month contribution period, register with the local unemployment service and be able to accept a job (art. 8 LACI). Although the law does not require special eligibility conditions for foreigners, some of the conditions mentioned before (like residence or prior contribution periods) are harder to fulfill by non-Swiss residents. In particular, a foreigner, although he/she is insured, may not qualify for unemployment benefits if the issuance of a work permit is not granted (ATF $126 \mathrm{~V} \mathrm{376)} \mathrm{since} \mathrm{without}$ a permit, the applicant is not allowed to accept a job. This rule does not apply, however, to EU/EFTA nationals. Furthermore, the condition of residency applies to Swiss nationals and foreigners. Thus, insured persons living abroad cannot claim unemployment benefits under national law. Yet, nationals who move to EU/EFTA countries in search for work can export their unemployment benefits for a short period.

Under international law, frontier workers, no matter if Swiss or EU/EFTA nationals, have to apply for unemployment benefits in the country where they reside. Concerning the prior contribution period required by Swiss law, article 61 of Regulation $n^{\circ} 883 / 2004$ demands to aggregate periods accomplished in an EU/ EFTA country. This rule applies from the first work day (Rubin 2014) and the federal administration in the field of unemployment insurance expressively states that 
even a one-day work period is sufficient to grant aggregation..$^{20}$ According to Swiss law, Swiss citizens and EU/EFTA nationals with a permanent residence permit who return to Switzerland after having worked outside the European economic area are partly exempt from the prior contribution requirement (art. $14 \S 3 \mathrm{LACI}$ ).

Certain cantons have adopted local legislation concerning non-contributory unemployment benefits for persons who no longer qualify for benefits of the federal unemployment insurance. These legislations generally require residency in Switzerland, more particularly, in the canton concerned. In other cantons, unemployed persons who are no longer eligible for unemployment benefits of the federal unemployment insurance fall into social assistance and the corresponding regimes usually contain a residence clause.

\subsubsection{Health Care}

There are four social insurance schemes regulating access to health care in Switzerland: the federal law concerning mandatory sickness insurance (LAMal), the federal law concerning mandatory disability insurance (LAI), the federal law concerning mandatory accident insurance for workers (LAA), and the federal law concerning mandatory military insurance (LAM). The sickness insurance provided by LAMal contains two strings: a compulsory care insurance and a voluntary daily benefits insurance to compensate a loss of income in case of health-related incapacity to work. The first string is financed by individual premiums; employers do not contribute to this string. The health care provided must correspond to a legally defined list that includes nearly all medical practices necessary to treat the sick insured person. As the care insurance is mandatory, health insurers cannot exclude persons who are sick or require a waiting period, although the scheme is limited to persons residing or working in Switzerland. Except certain situations like emergency or treatments not available in Switzerland, care provided on Swiss territory only entitles to reimbursement. The second string that is supposed to provide benefits in cash offers a very limited protection (sickness cash benefits provided by LAMal often reach an average amount of not more than CHF 15.- per day) because the insurer is not legally obliged to cover a minimum amount. Therefore, most employers who want to cover their staff have to contract a private insurance that is not part of social security. Foreign residents can access health benefits in kind under the same conditions as national residents.

Like in all the other fields of social security, Switzerland applies EU Regulation $\mathrm{n}^{\circ} 883 / 2004$ which facilitates access to health care in cross border situations by prohibiting discrimination and by providing health care in the Member State of residence or short term stay (see also Eugster 2016). The competent State (for instance, Switzerland if the person is insured in Switzerland) has to pay for the health care

\footnotetext{
${ }^{20}$ seco, Administrative Ordinance on January 1st 2019, E11, p. 105.
} 
provided abroad. This Regulation applies to Swiss, EU and EFTA nationals. Benefits in cash must be paid regardless national residency clauses. Swiss national law does not contain any rules that grant health care especially to Swiss citizens living abroad, but if an individual is in need, the payment of health care provided abroad may, in certain cases, be based on Federal Act on Swiss Persons and Institutions Abroad, RS 195.1). Moreover, only one of the social security agreements ratified by Switzerland (with Germany) provides cross-border access to health care.

The accident insurance (LAA) provides health care and several cash benefits whenever a worker is victim of an accident (professional and non-professional accidents) or suffering from an occupational disease. Self-employed persons have access to the same benefits if they are insured on a voluntary basis. LAA does not contain any special rules differentiating between nationals and foreigners. However, self-employed persons who wish to adhere to the voluntary scheme must have their residency in Switzerland. This rule does not apply to persons falling into the scope of EU Regulations $n^{\circ} 883 / 2004$ and $n^{\circ}$ 987/2009.

Besides the sickness insurance, the Swiss pension system also provides benefits that cover certain health issues. The old-age insurance (AVS) and the disability insurance (AI) pay benefits in kind to insured persons that need long term care (Kieser 2020). Health care is provided by the disability insurance to children and young persons under the age of 20 if they suffer from a congenital defect (article 13 LAI). Some exceptions apart, young foreigners born outside Switzerland do not qualify for benefits from LAI including health care in case of a congenital defect (art. $6 \S 2$ LAI). They may however get health care from the Swiss illness insurance (LAMal).

\subsubsection{Pensions}

Three federal laws regulate access to the Swiss public pension system: LAVS, LAI and LPC. The pension scheme is mandatory for persons living or working in Switzerland. Old-age pensions are provided after a contributory minimum period of 1 year but the amount of the pension depends on the number of years of contributions and the income gained during those years (Valterio 2011). Under certain conditions, non-contributory pensions are paid to Swiss, EU and EFTA citizens who do not fulfill the minimum period of 1 year, but these conditions are seldom fulfilled (the applicant needs to have domicile and permanent residency in Switzerland and must have been insured without any interruption). Furthermore, in addition to the contributory pension, non-contributory old-age, survivor and disability benefits are paid to pension holders if their pension does not cover the vital minimum. Pension holders must reside in Switzerland to receive non-contributory benefits. The voluntary access to the pension scheme for persons who are living or working abroad is restricted to Swiss, EU and EFTA nationals. These rules concern persons working for the Swiss Government or for certain International organizations and persons living outside Switzerland or in EU/EFTA countries (LAVS). For posted workers and 
students, the nationality does not make a difference. For instance, no matter if the worker is Swiss or not, he/she remains insured while working abroad for an employer based in Switzerland. Independently from any gainful activity, Swiss citizens (as well as EU citizens) may adhere to the public pension system on a voluntary basis if they are living in a third country (i.e. outside Switzerland, the EU or the EFTA); this possibility, however, is subject to a five-year prior insurance period. Persons who do not remain insured while working or living abroad will have a shorter contribution period and will - pro rata temporis - receive a smaller pension. The same rules apply, mutatis mutandis, for the disability insurance.

Swiss citizens residing abroad are entitled to claim public pensions from Switzerland, but foreigners must have their domicile and permanent residence in Switzerland. For foreigners falling into the scope of a bilateral agreement or the EU Regulations $\mathrm{n}^{\circ} 883 / 2004$ and $\mathrm{n}^{\circ}$ 987/2009, the residence condition is waived and pensions are exportable no matter in which country they choose to reside. Other foreigners who do not get a pension because they move out of Switzerland are able to get a part of their contributions back (Valterio 2011).

At the federal level, individuals who receive pensions from the public pension scheme (LAVS/LAI) may qualify for a complementary non-contributory pension (LPC). The system is implemented by the 26 cantons which may adopt rules that improve the benefits provided by LPC. LPC requires pension holders to reside in Switzerland and EU Regulation $n^{\circ}$ 883/2004 does not waive this condition. From July 2018 onward, additional requirements apply to foreigners, as complementary benefits are provided to foreigners only if they have a legal residency in Switzerland and 10 years of prior residence. For EU/EFTA citizens, however, the 10 years requirement is waived by Regulation 883/2004. The complementary pension schemes (second pillar: LPP and supplementary benefits) do not stipulate discriminating rules concerning foreigners. An insured person who leaves the country has the right to ask the pension fund for repayment of his/her assets; concerning LPP benefits, this rule does not apply to persons covered by EU Regulations n ${ }^{\circ}$ 883/2004 and $\mathrm{n}^{\circ} 987 / 2009$.

\subsubsection{Family Benefits}

Switzerland has introduced family benefits but does not provide parental leave. Family benefits have been regulated mainly by the legislation of the 26 cantons, although the federal legislator adopted a legal framework (LAFam) in 2006 aiming to harmonize this policy area. Family benefits are provided to workers and selfemployed persons who are insured as such by the public pension scheme (AVS). The presence of one or more children, no matter their nationality, triggers the right to family benefits. The law does not stipulate any other condition concerning citizenship. No prior contribution period is required to access these benefits, although article 7 of the Ordinance (OAFam, RS 836.21) requires residence in Switzerland as an eligibility condition (condition waived by EU Regulation $\mathrm{n}^{\circ}$ 883/2004). 
Furthermore, OAFam reserves birth allowance to mothers who have been living in Switzerland for at least 9 months before giving birth (this allowance is not included in Regulation $\left.n^{\circ} 883 / 2004\right)$. Federal law contains no rules that allow non-resident Swiss citizens to receive family benefits from Switzerland. The law of the 26 cantons might contain rules that restrict certain types of family benefits to Swiss citizens (e.g. Ticino, ATF 143 I 1).

The maternity benefits scheme (LAPG, RS 834.1- see also Geiser et al. 2019) is inspired by Directive 92/85/EEC concerning pregnant workers and workers who have recently given birth. LAPG covers female workers and self-employed working in Switzerland who have been insured in the public pension scheme (AVS) during 9 months before giving birth and have worked at least 5 months during this period. For Swiss/EU/EFTA nationals, Regulation $n^{\circ} 883 / 2004$ provides aggregation of periods accomplished in an EU/EFTA Member state. The LAPG scheme grants benefits during 14 weeks, at $80 \%$ of the average income previously earned.

\subsubsection{Guaranteed Minimum Resources}

As mentioned, the public pension scheme (1st pillar) is supplemented by noncontributory benefits granting minimum resources to pension holders (LPC). Besides this, Swiss law also provides social aid to persons in need. The access to social assistance is mainly based on the legislation of the 26 cantons, although a certain harmonization is ensured via cooperation between the cantons (Conférence Suisse des institutions d'action sociale, CSIAS). As a common denominator, social assistance or social aid is provided to persons living in Switzerland who cannot cover their basic living costs. Benefits include basic living and housing costs. In addition, the federal law provides benefits that allow to pay the mandatory social health insurance (LAMal), while also granting the right to assistance for persons in need, including access to indispensable health care (see also Gächter and Filippo 2015).

In most cantons, social assistance is restricted to persons living in the canton. EU Regulation $n^{\circ} 883 / 2004$ is not applicable to social assistance, but the Free Movement of Persons Agreement mentioned above contains rules concerning non-contributory benefits and social aid. The Agreement grants equal treatment with respect to welfare benefits for EU/EFTA nationals who qualify as workers but it allows Switzerland to not provide social assistance to non-active foreigners (art. 24 annex I FMPA and EU Directive 2004/38EC on the right of citizens to move and reside freely within the territory of the Member States). Concerning persons who lose their job, the law excludes them from social aid (art. 61a $\$ 3$ FNA). Moreover, foreigners can lose their residency permit if claiming or obtaining social aid. According to FNA, the competent authority may revoke a permit if a foreigner or a person the foreigner must care for is dependent on social assistance.

Federal law also provides social aid for Swiss citizens living abroad. The Federal Act on Swiss Persons and Institutions Abroad (SAA, RS 195.1) concerns Swiss 
citizens who are not domiciled in Switzerland and who are registered as such in the Swiss Abroad Register. The Swiss Confederation grants social assistance to nonresident Swiss who are in need and "unable to support themselves or with their own resources, with financial assistance from private sources or with assistance from the receiving state" (art. 24 SAA). The type and the amount of social aid depend on the conditions in the receiving state. The applicant may be advised to return to Switzerland if this is in his/her interest and the Confederation covers the travel costs. Once the person is back in Switzerland, the canton of residence becomes competent to provide social assistance if needed.

\subsection{Conclusions}

This chapter has shown that the Swiss social security system covers individuals who live and/or work in Switzerland. In general, the law does not distinguish between nationals and foreigners, besides certain exceptions concerning access to voluntary schemes, disability benefits and unemployment benefits. Social assistance is limited to persons residing in Switzerland. Most of the national rules, however, are subject to social security coordination which arises from the Free Movement of Persons Agreement applied to EU/EFTA nationals. In the future, the implementation of FMPA and Regulation $n^{\circ}$ 883/2004 might even be strengthened by an Agreement on institutional matters that the EU and Switzerland have drafted in December 2018. ${ }^{21}$ This Agreement provides for a dispute settlement that allows to bring a dispute before the European Court of Justice and thus promises a more homogenous application of EU law within the in Free Movement of Persons Agreement.

Acknowledgements This chapter is part of the project "Migration and Transnational Social Protection in (Post) Crisis Europe (MiTSoPro)" that has received funding from the European Research Council (ERC) under the European Union's Horizon 2020 research and innovation programme (Grant agreement No. 680014). In addition to this chapter, readers can find a series of indicators comparing national social protection and diaspora policies across 40 countries on the following website: http://labos.ulg.ac.be/socialprotection/.

\section{References}

Binswanger,P.(1950).KommentarzumBundesgesetzüberdieAlters-undHinterlassenenversicherung. Zürich: Polygraphischer Verlag.

Eugster, G. (2016). Krankenversicherung. In U. Meier (Ed.), Soziale Sicherheit/Sécurité sociale (pp. 579-594). Basel: Helbing Lichtenhahn.

\footnotetext{
${ }^{21} \mathrm{https} / /$ www.eda.admin.ch/dam/dea/en/documents/abkommen/InstA-Wichtigste-in-Kuerze_ en.pdf, Accessed 15 January 2019.
} 
Frésard-Fellay, G., \& Frésard, M. (2018). Règles de coordination. In A. S. Dupont \& M. MoserSzelless (Eds.), Loi sur la partie générale du droit des assurances sociales (pp. 786-789). Basel: Schulthess.

Gächter, T., \& Filippo, M. (2015). Stärkt der neue « Grundversorgungsartikel » der schweizerischen Bundesverfassung das « Recht auf Gesundheit» ? Bioethica Forum, 8(3), 85-90.

Geiser, T., Müller, R., \& Pärli, K. (2019). Arbeitsrecht in der Schweiz. Bern: Stämpfli.

Kahil-Wolff, B. (2015). Association agreements. In M. Fuchs \& R. Cornelissen (Eds.), EU social security law (pp. 536-548). Baden-Baden: NOMOS.

Kahil-Wolff, B. (2017). Droit social européen. Zürich: Schulthess.

Kieser, U. (2020). ATSG-Kommentar. Zürich: Schulthess.

Riemer-Kafka, G. (2018). Schweizerisches Sozialversicherungsrecht. Bern: Schulthess.

Rubin, B. (2014). Commentaire de la loi sur l'assurance-chômage. Zurich: Schulthess.

Valterio, M. (2011). Droit de l'assurance-vieillesse et survivants (AVS) et de l'assurance-invalidité (AI). Zurich: Schulthess.

Open Access This chapter is licensed under the terms of the Creative Commons Attribution 4.0 International License (http://creativecommons.org/licenses/by/4.0/), which permits use, sharing, adaptation, distribution and reproduction in any medium or format, as long as you give appropriate credit to the original author(s) and the source, provide a link to the Creative Commons license and indicate if changes were made.

The images or other third party material in this chapter are included in the chapter's Creative Commons license, unless indicated otherwise in a credit line to the material. If material is not included in the chapter's Creative Commons license and your intended use is not permitted by statutory regulation or exceeds the permitted use, you will need to obtain permission directly from the copyright holder. 